\title{
Küresel İklim Değișikliğinin Fotosentez Üzerine Etkileri
}

\section{İlkay YAVAȘ ${ }^{* 1}$ (D), Aydın ÜNAY ${ }^{2}$}

\author{
' Aydın Adnan Menderes Üniversitesi, Koçarlı Meslek Yüksek Okulu, Çakmar Aydın \\ ${ }^{2}$ Aydın Adnan Menderes Üniversitesi, Ziraat Fakültesi, Tarla Bitkileri Bölümü, Çakmar Aydın
}

Öz: Küresel iklim değișikliğinin sonucu olarak artan karbondioksit, sıcaklık ve kuraklık faktörleri ve karșılıklı etkileșimleri fotosentezi etkilemektedir. Bitkilerde $C_{3}$ ve $C_{4}$ gibi farkı fotosentez mekanizmalarının yanı sıra $C_{4}$ bitkilerinde NAD-malik enzim (NAD-ME), NADP-malik enzim (NADP-ME) ve PEP karboksilaz olmak üzere üç alt tür olduğu gözlenmektedir. NADME bitkilerinin kurak koșullar altında su kullanım etkinliği, NADP-ME bitkilerine göre daha fazla olup, NAD-ME $C_{4}$ bitkileri artan $\mathrm{CO}_{2}$ koșullarında daha iyi büyüme ve fotosentez etkinliğine sahiptir. $\mathrm{C}_{4}$ bitkileri artan $\mathrm{CO}_{2}$ koșullarına, diğer bitki türlerine göre daha az tepki göstermekte buna karșın suyu ve azotu daha etkin kullanmaktadır. Bu nedenle buğday ve çeltik bașta olmak üzere bazı $C_{3}$ bitkilerine $C_{4}$ yolunun aktarılması yönünde ıslah çalıșmaları devam etmektedir

\section{Anahtar Kelimeler: $C_{3}, C_{4}$, kuraklık, sıcaklık, fotosentez}

\section{The Effects of Global Climate Change on Photosynthesis}

\begin{abstract}
As a consequence of global climate change, increasing carbon dioxide, temperature and drought factors and their interactions are affecting photosynthesis. In addition to different photosynthesis mechanisms such as $C_{3}$ and $C_{4}$ in plants, $C_{4}$ plants have three subspecies: NAD-malic enzyme (NAD-ME), NADP-malic enzyme (NADP-ME) and PEP carboxylase. The NAD-ME plants had more water use efficiency under arid conditions than NADP-ME plants, NAD-ME C4 plants have better growth and photosynthesis activity under increasing $\mathrm{CO}_{2}$ conditions.

C4 plants show less response to increased $\mathrm{CO}_{2}$ conditions than other plant species on the other hand, it uses water and nitrogen more effectively. For this reason, some $C_{3}$ crops especially wheat and rice are undergoing breeding experiments to transfer the $C_{4}$ pathway.
\end{abstract}

Keywords: $C_{3}, C_{4}$, drought, temperature, photosynthesis

\section{GiRiș}

Küresel iklim değișikliğinin bitkisel üretime etkileri, verim, gıda güvenliği, kültür bitkilerinin coğrafik dağııımı ve türlerin kompozisyonu, zararlı ve hastalıklar üzerine etkisi, $C_{3} / C_{4}$ ve kültür bitkisi/yabancı ot etkileșimleri, tohumluk üretimi ve tozlanma gibi ana bașlıklar altında incelenmektedir (Singh ve ark., 20I3). Yirmi üç kültür bitkisine ait alanın daralacağı buna karșın 20 bitkinin alanının artacağı öngörülmektedir (Lane ve Jarvis, 2007). Ekolojik olarak en fazla alan artıșı hint darısı (Pennisetum glaucum L.), ayçiçeği, soya, kum darısı ve nohutta olurken börülce, yer fistığı ve patates yabani türlerinin 2050 yılına kadar yok olacağı bildirilmiștir.

Küresel iklim değișikliği sürecinde artan sıcaklığın olumsuz etkileri ile $\mathrm{CO}_{2}$ artıșının yol açtığı olumlu etkiler denge olușturmaktadır (Prasad ve ark., 2005). Sicaklık stresinin bitkiler için en önemli bir biyolojik fonksiyon olan fotosentez üzerinde oldukça kritik etkiye sahip olduğu bildirilmiștir (Ding ve ark., 2016). $\mathrm{CO}_{2}$ içeriğinin artması ile birlikte bazı bitkilerin bundan olumlu yönde etkileneceği hatta $\mathrm{CO}_{2}$ miktarının artmaya bașladığı sanayi devriminden bu yana bu bitkilerdeki verim artıșının $\mathrm{CO}_{2}$ içeriğindeki artıșa bağlı olduğu tartıșılmaktadır. Sıcaklıkların artması bitki gelișisim dönemlerini kısaltmakta, ekimde ve hasatta erkenciliğe yol açmaktadır (Bayraç ve Doğan, 2016). Küresel iklim değișikliğinin beraberinde getireceği yeni çevre koșullarının ıslah çalıșmalarındaki seleksiyon ölçütlerini etkileyeceği belirtilmiștir (Singh ve ark., 2013).

Bitki ıslahı yönünden küresel iklim değișikliği senaryolarına göre ıslah hedefleri geliștirilmiștir (Ceccarelli ve ark., 2010). Sıcaklık ve $\mathrm{CO}_{2}$ içeriğindeki artıșların bitkilerdeki fotosentez kapasitesini nasıl etkileyeceği konusunda çok sayıda çalıșma yapılmıștır. Bu çalıșmalar kültür bitkileri ile birlikte bitki florası yayıııșının $C_{3}$ veya $C_{4}$ bitkisi yönünde olup olmayacağı konusunda yoğunlașmıștır. Yeryüzündeki farklı sıcaklık ve yağıș rejimlerinin $C_{3}$ bitkileri ile birlikte $C_{4}$ bitkileri içerisindeki farklı alt tiplerinin yayılıșına olan etkileri ortaya konulmuștur. Bu derlemede özellikle fotosentez üzerinden gelecekteki değișikliğin hangi bitki türlerinde önemli olacağını belirlemek, bitkiler üzerine etkili çevresel faktörlerin fotosentez mekanizmasında yol açtığı farklılıklar ve $C_{3}$ bitkilerine $C_{4}$ fotosentez yolunu aktarmadaki islah çalıșmalarının bașarısının ortaya konulması amaçlanmıștır.

\section{$C_{3}$ ve $C_{4}$ Bitkilerinde Fotosentez}

$C_{3}$ ve $C_{4}$ bitkilerinde ıșık reaksiyonları benzer olmasına karșın $\mathrm{CO}_{2}$ özümleme reaksiyonları farklılık göstermektedir. Aynı zamanda $\mathrm{C}_{4}$ fotosentezi içerisinde mezofil hücrelerinde gerçekleșen 4 karbonlu asitleri dekarboksilasyona uğratan enzimler farklıdır. $\mathrm{Bu}$ farklılığa göre $\mathrm{C}_{4}$ fotosentez mekanizması üç alt sınıfa ayrılmaktadır. Bunlar NAD'ye bağlı malik enzim (NAD-ME), NADP'ye bağlı malik enzim (NADP-ME) ve PEP karboksikinazdir (PEPCK) (Hatch, 1987). Mısır (Zea mays), șeker kamıșı (Saccharum sp.) ve sorgum (Sorghum bicolor) gibi bitkiler NADP-ME $C_{4}$ alt sınıfında yer almakta buna karșın dallı darı (Panicum virgatum L.), hint darısı (Pennisetum glaucum L.) ve horozibiği (Amaranthus sp.) gibi bitkiler NAD-ME tipini olușturmaktadır (Rao ve Dixon, 2016). NAD-ME ve NADPME tipleri çift çeneklilerde hemen hemen eșit sayıda tür içermekte iken NADP-ME tek çeneklilerde daha yaygın durumdadir.

Artan $\mathrm{CO}_{2}$ koșullarında karșı foto-solunumun azalması ve

Sorumlu Yazar: iyavas@adu.edu.tr

Geliș Tarihi: 29 Mart 2018

Kabul Tarihi: 8 Ekim 2018 
fotosentez etkinliğinin yüksek olması nedeniyle $C_{4}$ fotosentez mekanizması verimliliği artırmanın yolu olarak öngörülmüștür (Leegood, 2002). Atriplex sp. (tuz çalısı) cinsinin $C_{3}$ ve $C_{4}$ türleri melezlenmiș olmasına rağmen $C_{4}$ bitkilerindeki fotosentez anatomisi, artan PEP karboksilaz etkinliği ve düșük doyma noktası gibi özelliklerin kalıtımı bitki ıslahının bașarısını kısıtlamıștır. Buna karșın genetik mühendisliğindeki ilerlemeler tütün, patates ve çeltik gibi bitkilerde $C_{3}$ yolunun içerisine $C_{4}$ yolunun genetik manipilasyonunu olası kılmıștır (Matsuoka ve ark., 200I). $C_{4}$ fotosentezindeki karmașık anatomik yapıyı üretmekten veya aktarmaktan ziyade $\mathrm{C}_{4}$ yolunun enzimlerinin üretimi üzerinde durulmuștur. Son yıllarda $\mathrm{CO}_{2}$ özümlemesinde mezofil ve demet kını hücreleri yerine tek hücre tipli $C_{4}$ yolu üzerinde yoğunlașılmıștır. Bu tarzdaki bitki tipi olarak bir su bitkisi olan Hydrilla verticillata bulunmuștur (Leegood, 2002).

\section{Karbondioksit Artıșının Bitkiler Üzerine Etkisi}

Genel bir değerlendirme yapıldığında $\mathrm{CO}_{2}$ içeriğindeki artıșın fotosentez üzerinde pozitif bir etkiye sahip olduğu düșünülmektedir. Bitkiler tarafından stomatal olarak alınan atmosferik karbondioksit yaprak dokusunda mezofil hücreleri arasındaki boșluklarda bulunmaktadır. Teorik olarak, ortam nemli olduğunda bile su kaybını sağlayan iki ortam arasındaki potansiyel farklıık $\mathrm{CO}_{2}$ alınımı için olan potansiyel farklılıktan 50 kat daha büyüktür. Hatta kuru hava koșularında bu fark daha da yüksektir ve böylelikle stomatal direnç azalmakta ve daha fazla $\mathrm{CO}_{2}$ emilimi gerçekleșmektedir. Ancak bu gerçekleșirken su kayıpları artmaktadır (Vince ve Zoltan, 20l I).

Temel çalıșmalarda, hücreler arası boșlukta yer alan içsel $\mathrm{CO}_{2}$ içeriği ıșık șiddetinin yeterli olduğu durumlarda fotosentezde kullanılması sonucu azalmaktadır (Whiteman ve Koller, 1967). Bu nedenle $\mathrm{CO}_{2}$ artıșının bitkiler üzerine etkilerinin belirlendiği sera çalıșmalarında su ve azot etkileșimi yanında ıșığın optimum kılınması önem tașımaktadır. Bu çalıșma kusurlarını ortadan kaldıran FACE (Free-Air CO2 Enrichment) yöntemiyle açık alanda $\mathrm{CO}_{2}$ içeriği artıșının incelendiği çalıșmalarda; $\mathrm{CO}_{2}$ artıșının stoma iletkenliği ve yaprakta stoma sayısını azalttığı bildirilmiștir (Teng ve ark., 2006; Leakey ve ark., 2009; Xu ve ark., 20 I6; Swann ve ark., 2016). Ayrıca, Teng ve ark. (2006) tarafından $\mathrm{CO}_{2}$ artıșının olduğu koșullarda kloroplast sayısı, genișliği ve alanı, karbonhidrat tane iriliği artarken, granum tilakoid membran sayısının azaldığı buna karșın stroma tilakoid membran miktarının arttığı (Griffin ve ark., 200I) saptanmıștır.

$\mathrm{CO}_{2}$ ve sıcaklık fotosentezi etkileyen iki önemli faktördür. Mevcut atmosferik $\mathrm{CO}_{2}$ içeriği $\mathrm{C}_{3}$ bitkilerinin fotosentez kapasitesini sınırlamaktadır. Buna karșın küresel iklim değișikliği ile birlikte olası $\mathrm{CO}_{2}$ içeriğinin artması bu bitkilerin fotosentez kapasitesini olumlu yönde etkileyebilir. $\mathrm{CO}_{2}$ miktarı artıșına bitkilerin tümü aynı tepkiyi vermemektedir. $\mathrm{C}_{4}$ bitkileri diğer bitki türlerine göre $\mathrm{CO}_{2}$ miktarı artıșına daha az tepki göstermektedir. C4 bitkilerinde PEP karboksilaz enzimi 4 karbonlu okzalasetat asidini olușturmak için bikarbonat $\left(\mathrm{HCO}_{3}^{-}\right)$'ı kullanmaktadır. Yani atmosferden mezofil hücrelerine giren $\mathrm{CO}_{2}$ karbonik anhidraz tarafından hızla bikarbonata dönüștürülür (Badger ve Price, 1994). PEP karboksilaz enzimi azot asimilasyonu ve amino asit biyosentezi için gerekli malat ve oksalasetat'ın yenilenmesinde rol oynamaktadır. PEP karboksilaz aktivitesi yoluyla malat sentezi sitoplazmada $\mathrm{pH}$ düzenlemesini de kapsamaktadır. Bu enzim ayrıca stoma açma-kapama hücrelerindeki rolüyle atmosfer ve yaprak dokusu arasındaki $\mathrm{CO}_{2}$ ve su değișimini düzenlemektedir. Ana görev olarak da mezofil hücrelerindeki $\mathrm{C}_{4}$ fotosentezinin karboksilasyon zincirini katalize etmektedir. Yaprak dokusunun fotosentezdeki $\mathrm{CO}_{2}$ asimilasyon kapasitesi büyük oranda Rubisco içeriğine bağlıdır. Atmosferdeki düșük veya orta düzeydeki $\mathrm{CO}_{2}$ içeriği $\mathrm{C}_{3}$ bitkilerindeki Rubisko'nun karboksilasyon aktivitesini sınırlamaktadır. Yüksek $\mathrm{CO}_{2}$ içeriğinde fotosentezin ıșık reaksiyonlarındaki elektron tașıma oranına bağlı olarak $\mathrm{CO}_{2}$ alıcısı olan Ribuloz I,5bisfosfatın tekrar üretiminde Calvin-Benson döngüsünün kapasitesi etkili olmaktadır. İki önemli $C_{3}$ bitkisi olan buğday ve çeltiğin karșılaștırıldığı çalıșmalarda buğdaydaki Rubisko enziminin karboksilasyon/oksigenaz etkinliğinin daha yüksek olduğu bildirilmiștir (Nagai ve Makino, 2009). C4 bitkilerinde mezofil hücrelerde sentezlenen 4 karbonlu bileșikler demet kını hücrelerindeki $\mathrm{CO}_{2}$ kaynağıdır. $\mathrm{Bu}$ nedenle $\mathrm{C}_{4}$ bitkilerinin düșük $\mathrm{CO}_{2}$ koșullarında bile fotosentez hızı yüksektir. Teorik olarak, asimile edilen net $\mathrm{CO}_{2}$ miktarının birim yaprak azot içeriğine olan oranı "fotosentetik azot kullanım etkinliği” (Leakey ve ark., 2009); net fotosentezde yaprak karbon kazancının birim yaprak bașına transpirasyonla su kaybına oranı "fotosentetik su kullanım etkinliği” (Way ve ark., 2014) olarak tanımlanmıștır. $\mathrm{CO}_{2}$ miktarının arttığı koșullarda $C_{4}$ bitkilerinin $C_{3}$ bitkilerine oranla suyu ve azotu daha etkin kullandığı belirlenmiștir (Sage ve Percy, 1987; Leakey ve ark., 2009).

$C_{3}$ ve $C_{4}$ bitkilerinin içerisinde yer aldığı çok sayıda bitki türü ile yapılan çalıșmalarda maksimum karboksilasyon oranı, elektron aktarım oranı, her iki parametrenin birbirlerine oranı ve rubisko içerinin artan $\mathrm{CO}_{2}$ koșullarına tepki olarak azaldığı belirtilmiștir. Benzer șekilde belli bir yaprak alanı ve kütlesinde azot ve klorofil içeriğinin azaldığı saptanmıștır. Buna karșın artan $\mathrm{CO}_{2}$ koșullarına tepki olarak birim alan yaprakta șeker ve nișasta miktarının arttığı tespit edilmiștir (Ainsworth ve ark., 2004).

$\mathrm{C}_{3}$ bitkisi olan pamuk ile yapılan çalıșmalarda $\mathrm{CO}_{2}$ içeriğindeki artıșların optimum sıcaklıklarda bitki büyümesi için karbon asimilasyonunu arttırarak verimi artıracağı öngörülmüștür. Buna karșın yüksek sıcaklık koșullarında düșük koza ağırlığı nedeniyle verimin azalacağı saptanmıștır (Reddy ve ark., 1995). Bunun yanında artan $\mathrm{CO}_{2}$ miktarına maruz kalan pamuk bitkisinde karbon: azot (C:N) oranı, tanin, gosipol, bitki boyu, biyokütle, yaprak alanı ve azot içeriğinin önemli ölçüde daha yüksek olduğu gözlenmiștir (Gao ve ark., 2010). Atmosfer içeriğindeki interaksiyonlar da önemli olmaktadır. $\mathrm{CO}_{2}$ ve $\mathrm{O}_{3}$ seviyelerindeki birlikte artıș incelendiğinde; yüksek $\mathrm{CO}_{2}$ seviyesinin stomatal iletkenliği azalttığı buna karșın stoma yoluyla giriși engelleyerek ozonun neden olduğu oksidatif hasarı iyileștirdiği tespit edilmiștir (Oksanen ve ark., 200I; Abdelhaliem ve Al-Huqail, 2016).

$\mathrm{CO}_{2}$ özümleme mekanizması olarak $\mathrm{C}_{3}, \mathrm{C}_{4}$ ve $\mathrm{CAM}$ bitkileri olarak gruplandırılsa da $\mathrm{C}_{3}-\mathrm{C}_{4}, \mathrm{C}_{3}-\mathrm{CAM}$ (Sedum telephium), 
$\mathrm{C}_{4}-\mathrm{CAM}$ ve $\mathrm{C}_{4}$ benzeri türler (Flaveria brownii) de bulunmaktadır. Bu geçiș formlarının en yaygın olanı $\mathrm{C}_{3}-\mathrm{C}_{4}$ (Flaveria pubescen; Cleome spp.; Panicum spp., Alternanthera spp.) geçiș formundaki bitkilerdir. Bu bitkiler fotorespirasyon oranlarının düșük olması ve bu nedenle sıcak ve kurak iklimlere uyumları ile dikkati çekmektedir. $C_{3}$ ve $\mathrm{C}_{4}$ bitkileri arasındaki geçiș formlarının olması $C_{3}$ bitkilerine $\mathrm{C}_{4}$ yolunun aktarılması ıslahını beraberinde getirmiștir. Yukarıdaki farklılıklara karșın tüm $\mathrm{C}_{4}$ bitkilerinin sıcak ve kurak iklimlerde daha yüksek büyüme oranlarına sahip olduğu bildirilmiștir. Bu nedenle buğday ve çeltik gibi iki $C_{3}$ bitkisine $C_{4}$ fotosentez yolunun aktarılması amaçlanmaktadır. Buğdayda yapraklarda olmayan bu mekanizmanın karyopsis durumundaki perikarp dokusunda olduğu belirlenmiștir. Çalıșmalarda $C_{3}$ bitkisine $C_{4}$ yolunun aktarımı ile küresel iklim değișikliğine uyum amaçlanmıștır. Çeltikte ise geçiș formlarındaki genlerin fonksiyonel ișleyișleri transkriptom çalıșmalarıyla belirlenmiștir. $C_{4}$ çeltiğin transgenik olarak bașarıya ulașması sonrasında yerel çeșitlere bu mekanizmanın aktarılması amaçlanmaktadır (Wang ve ark., 20I6).

\section{Sıcaklık Artıșı}

İklim değișikliğinin en belirgin olumsuz etkisi, bitki gelișimi üzerine yüksek sıcaklığın zararlı etkileri nedeniyledir. Bunun olumsuz etkileri çoğunlukla kuraklık ve tuzluluk stresi ile birlikte değerlendirilmektedir. Artan sıcaklıkların olumsuz etkileri arasında en önemli olanı gelișme dönemi sürelerinin farklılașması olarak belirtilmiștir (Ủlukan, 2010; Önen ve Özcan, 2010; Bita ve Gerats, 2013; Sayılğan, 2016). Sıcaklığın meristem/organ büyümesini teșvik ederek daha hızlı gelișime neden olacağı ve bunun büyüyen organlara asimile edilen sürenin kısalmasına, daha küçük bitki organeli ve daha az biokütle birikimine yol açacağı (Morison ve Lawlor, 1999) ve genellikle generatif döneme erken geçiși (Hedhly ve ark., 2008) meydana getireceği vurgulanmıștır. Morfolojik olarak bitki yapısının değișeceği ve hipokotil ile petiollerin gölgeden kaçıș tepkisine benzer olarak uzayacağı belirtilmiștir (Hua 2009). Yüksek sıcaklıklar bitkiyi tüm gelișim evrelerinde etkilemekle birlikte özellikle tozlanma ve tane dolum gibi gelișme dönemleri üzerindeki etkisi oldukça yüksektir (Bayraç ve Doğan, 20l6).

Sıcaklık stresinin enzim aktivitesi, membran akıșkanlığı, protein kompleksleri olușumu, klorofil sentezi, fotosentez ve solunumu içeren bitki hücre fonksiyonlarında değișikliğe neden olacağı vurgulanmıștır. İklim değișikliklerinin gece gündüz sıcaklık farklılıklarında değișikliklere yol açacağı (Önen ve Özcan, 20I0) ve özellikle de minimum sıcaklıkları artıracağı düșünülmektedir (Pathak ve ark., 2009; Ton, 20II).

$\mathrm{C}_{4}$ bitkilerinin fotosentez verimliliği üzerine sıcaklığın etkisini saptamak amacıyla yürütülen çalıșmalar yüksek sıcaklıktan ziyade düșük sıcaklıklar üzerine yoğunlașmıștır. Buna karșın yüksek sıcaklığın etkisini belirlemek için yapılan çok az sayıda çalıșmada $38{ }^{\circ}$ C'nin üzerindeki yaprak sıcaklıklarının mısır bitkisindeki net fotosentezi engellediği fakat fotosistem II erkinliğinin $45{ }^{\circ}$ C'nin üzerindeki sıcaklıklarda bile devam ettiği saptanmıștır. $\mathrm{C}_{4}$ bitkilerinin $\mathrm{CO}_{2}$ özümleme mekanizmasındaki fosfoenolpirüvat karboksilaz enziminin $40{ }^{\circ} \mathrm{C}$ ' nin üzerindeki sıcaklıklarda etkinliğinin azaldığı buna karșın pirüvat fosfat dikinaz etkinliğinin ise $45^{\circ}$ C'nin üzerindeki sıcaklıklarda bile devam ettiği bulunmuștur. Tüm bunlara karșın hem $C_{3}$ hem de $C_{4}$ fotosentez mekanizmasındaki Rubisco enzimi etkinliğinin ise $32.5^{\circ}$ C'yi așan sıcaklıklarda azaldığı ve $45^{\circ}$ C'nin üzerinde etkinliğini tamamen yitirdiği saptanmıștır. Bu, bitkilerdeki fotosentetik etkinliğin Rubisco enzimine bağlı olduğu (Crafts-Brandner ve Salvucci, 2002; Feller, 2016) ve buna bağlı olarak $\mathrm{CO}_{2}$ değișim oranının (CER) azaldığı (Law ve Crafts-Brander, 1999) saptanmıștır. Aynı șekilde her ikisi de $\mathrm{C}_{3}$ bitkisi olan buğday ve çeltiğin fotosentez etkinliği üzerine sıcaklığın etkisinin belirlendiği çalıșmada buğdayın performansının çeltikten daha iyi olduğu ve bunun buğdaydaki Rubisco enzim aktivitesinin daha yüksek olmasından kaynaklandığı ifade edilmiștir (Nagai ve Makino, 2009).

Buğdayda yüksek sıcaklık stresi tilakoid membranların zararını artırmakta ve bu zararlanma klorofil kaybını beraberinde getirmektedir. Bu nedenle klorofil miktarının saptanmasının buğdayda yapılacak ıslah çalıșmalarındaki gözlem analizlerinde bașarı ile kullanılabileceği belirlenmiștir (Bita ve Gerats, 20I3). Benzer șekilde çeltikte yüksek sıcaklığa toleranslı genotip yüksek fotosentez kapasitesine sahip, yapraklarda yeșil kalma süresi uzun ve dolayısı ile membran termostabilitesi yüksek olarak tanımlanmıștır (Scafaro ve ark., 20l0).

\section{Kuraklık}

Küresel iklim değișikliği modelleri kuraklık ve sıcak hava dalgası gibi sıra dıșı olayların sıklığının artacağını göstermektedir. Artan $\mathrm{CO}_{2}$ ve sıcaklığın beraberinde getirdiği kuraklık bitki fizyolojisinde önemli değișikliklere yol açmaktadır. Aslında en önemli değișiklik; $\operatorname{artan} \mathrm{CO}_{2}$ koșullarında kuraklık ile birlikte yaprak sıcaklığının artması ve sonucunda stomaların daha az açık olması nedeniyle transpirasyonun bitki iç sıcaklığını düșürememesidir (Feller, 2016). Beraberinde $\mathrm{CO}_{2}$ artıșında stomatal iletkenliğin azalması transpirasyon oranının azalıșına bağlı olarak su kullanım etkinliğini artırmaktadır. Buna karșın kuraklık stresi metabolizma ve fotosentezin engellenmesine neden olmaktadır. Stres koșullarında bitkilerin hayatta kalma yeteneği bitki türlerine, büyüme devresine, süresine ve su eksikliğinin șiddetine bağlı olarak değișmektedir (Tátrai ve ark., 2016).

Olası iklim değișikliklerinin bir sonucu olan su yetersizliği ve azot gibi koșullara adaptasyon yönünden $\mathrm{C}_{4}$ fotosentez kapasitesinin alt türlere göre değiștiği belirlenmiștir. $\mathrm{C}_{4}$ tipi içerisinde yer alan çim türleri ile ilgili araștırmalar NAD-ME alt türlerinin daha çok kurak alanlarda gözlendiğini, NADPME tiplerinin ise yıllık yağıș miktarı ve dağılıșının optimum olduğu alanlarda yaygınlaștığı saptanmıștır. NAD-ME çimleri kurak koșullarda yaprak yapısı ve daha hızlı yaprak kıvrılma oranı nedeniyle önemli bir șekilde daha fazla su kullanım etkinliği artıșı sağlamaktadır (Ghannoum ve ark., 2002; Liu ve Osborne, 20I5). Buna karșın NADP-ME tiplerinde yüksek azot kullanım etkinliği saptanmıștır.

\section{SONUÇ}

Küresel iklim değișikliği ve sera gazlarının olumsuz etkileri dünyanın farklı bölgelerinde önemli bir șekilde hissedilmekte ve giderek önem kazanmaktadır. Küresel iklim değișimi nedeniyle $\mathrm{CO}_{2}$ miktarındaki artıș, fotosentez ve karbon 
asimilasyon hızını etkilemesi nedeniyle $C_{3}$ bitkilerinin büyümesini ve verimini etkileyecektir. $C_{4}$ bitkileri sıcaklık artıșı ile beraber su kayıplarını azaltmak için stomalarını kapatacak oksigenaz aktivitesi artacak ve yapraklarda depolanan $\mathrm{CO}_{2}$ i kullanacaktır. $\mathrm{C}_{3}$ bitkileri ise $\mathrm{CO}_{2}$ yerine bitkide depolanan $\mathrm{O}_{2}^{\prime}$ yi kullanacaktır. $\mathrm{Bu}$ durum $\mathrm{C}_{4}$ bitkilerini ön plana çıkaracaktır. Küresel iklim değișiminin negatif etkilerinin en fazla $\mathrm{C}_{3}$ bitkisi olan buğdayda gözleneceği, buna karșın $C_{4}$ bitkisi olan mısır ve sorgum bitkilerinin veriminin ise daha yüksek olacağı tahminlenmektedir. Ayrıca tuzlu koșullar stomaların kapanmasına yol açacak, $\mathrm{CO}_{2}$ fiksasyonunun sınırlandırılması sonucu oksigenaz aktivitesi artıș gösterecektir.

\section{KAYNAKLAR}

Abdelhaliem E, Al-Huqail AA (20I6). Detection of protein and DNA damage induced by elevated carbon dioxide and ozone in Triticum aestivum L. using biomarker and comet assay. Genetics and Molecular Research, I5:DOI http://dx.doi.org/10.4238 /gmr. I5028736 [Erișim Tarihi: 10.10.2017]

Ainsworth EA, Rogers A, Nelson R, Long SP (2004). Testing the 'source-sink' hypothesis of down-regulation of photosynthesis in elevated $\mathrm{CO}_{2}$ in the field with single gene substitutions in Glycine max. Agricultural and Forest Meteorology 122: 85-94.

Badger MR, Price GD (1994). The Role of Carbonic Anhydrase in Photosynthesis. Annual Review of Plant Physiology and Plant Molecular Biology 45: 369-392.

Bayraç HN, Doğan E (20I6). Türkiye'de İklim Değișikliğinin Tarım Sektörü Üzerine Etkileri. Eskișehir Osmangazi Üniv. İ̈BF Derg. I I ( I):23-48.

Bita CE, Gerats T (20/3). Plant tolerance to high temperature in a changing environment: scientific fundamentals and production of heat stress-tolerant crops. Frontiers in Plant Sci. 4 (273): I- I8.

Ceccarelli S, Grando S, Maatougui M, Michael M, Slash M, Haghparast R, Rahmanian R, Taher A, Al-Yassin A, Benbelkacem A, Labdi M, Mimoun H, Nachit M (2010). Plant breeding and climate changes. Journal of Agricultural Science 148: 627-637.

Crafts-Brandner SJ, Salvucci ME (2002). Sensitivity of photosynthesis in a C4 plant, maize, to heat stress. Plant Physiol. 129: 1773-1780.

Ding $X$, Jiang $Y$, He L, Zhou Q, Yu J, Hui D, Huang D (20l6). Exogenous glutathione improves high root-zone temperature tolerance by modulating photosynthesis, antioxidant and osmolytes systems in cucumber seedlings. Scientific Reports 6: 35424 DOI: 10.1038/srep35424 [Erișim Tarihi: 25.02.2018]

Feller $U$ (2016). Drought stress and carbon assimilation in a warming climate: Reversible and irreversible impacts. Journal of Plant Physiology 203: 84-94.

Gao F, Chen F, Ge F (2010). Elevated CO2 lessens predation of Chrysopa sinica on Aphis gossypii. Entomol. Exp. Appl. I35: I35-I40.

Ghannoum O, von Caemmerer S, Conroy JP (2002). The effect of drought on plant water use efficiency of 9 NAD-ME and 9 NADP-ME C4 grasses. Functional Plant Biology 29:1 337-I348.
Griffin KL, Anderson OR Gastrich MD, Lewis JD, Lin G, Schuster W, Seemann JR, Tissue DT, Turnbull $M$, Whitehead D (200I). Plant growth in elevated CO2 alters mitochondrial number and chloroplast fine structure. Proceedings of the National Academy of Science of the USA 98: 2473-2478.

Hatch MD (1987). $C_{4}$ photosynthesis: a unique blender of modified biochemistry, anatomy and ultrastructure. Biochimica et Biophysica Acta 895: 357-369.

Hedhly A, Hormaza Jl, Herrero M (2008). Global warming and sexual plant reproduction. Trends Plant Sci. I: 3036.

Hua J (2009). From freezing to scorching, transcriptional responses to temperature variations in plants. Current Opinion Plant Biology 12: 568-573.

Lane A, Jarvis A (2007). Changes in climate will modify that geography of crop suitability: agricultural Biodiversity can help with adaptation. Open Access J. 4:I (ICRISAT).

Law RD, Crafts-Brandner SJ (1999). Inhibition and Acclimation of Photosynthesis to Heat Stress Is Closely Correlated with Activation of Ribulose-I,5Bisphosphate Carboxylase/Oxygenase. Plant Physiol. I20(I): 173-182

Leakey ADB, Ainsworth EA, Bernacchi CJ, Rogers A, Long SP, Ort DR (2009). Elevated $\mathrm{CO}_{2}$ effects on plant carbon, nitrogen, and water relations: six important lessons from FACE. Journal of Experimental Botany 60 (I0): 2859-2876.

Leegood RC (2002). $\mathrm{C}_{4}$ photosynthesis: principles of $\mathrm{CO}_{2}$ concentration and prospects for its introduction into $\mathrm{C}_{3}$ plants. Journal of Experimental Botany 53: 58I-590.

Liu $\mathrm{H}$, Osborne CP (2015). Water relations traits of $\mathrm{C}_{4}$ grasses depend on phylogenetic lineage, photosynthetic pathway, and habitat water availability. J. Exp. Bot. 66: $76 \mid-773$.

Matsuoka M, Furbank RT, Fukayama H, Miyao M (200I). Genetic engineering of $\mathrm{C}_{4}$ photosynthesis. Ann. Rev. Plant Physiol. Mol. Biol. 52: 297-3I4.

Morison JIL, Lawlor DW (1999). Interactions between increasing $\mathrm{CO}_{2}$ concentration and temperature on plants growth. Plant, Cell \& Environment 22: 659-682.

Nagai T, Makino A (2009). Differences Between Rice and Wheat in Temperature Responses of Photosynthesis and Plant Growth. Plant Cell Physiol. 50(4): 744-755.

Oksanen E, Sober J, Karnosky DF (200I). Impacts of elevated $\mathrm{CO}_{2}$ and/or $\mathrm{O}_{3}$ on leaf ultrastructure of aspen (Populus tremuloides) and birch (Betula papyrifera) in the Aspen FACE experiment. Environmental Pollution II 5: 437-446.

Önen H, Özcan S (2010). İklim Değișikliğine Bağlı Olarak Yabancı Ot Mücadelesi. Ed. Sayılı, M. 2010. İklim Değișikliğinin Tarıma Etkileri ve Alınabilecek Önlemler. T.C. Kayseri Valiliği İl Tarım Müdürlüğü. 2: 336-357. Fidan Ofset, Kayseri. 
Pathak H, Aggrawal PK, Singh SD (2009). Climate change impact, adaptation and mitigation in agriculture: methodology for assesement and applications. Indian Agricultural Research Institute. New Delhi. p:302.

Prasad P, Vara V, Allen Jr LH, Boote KJ (2005). Crop responses to elevated carbon dioxide and interaction with temperature: grain legumes. J. Crop Improv. 13: II3-I55.

Rao X, Dixon RA (2016). The differences between NADME and NAD-ME subtypes of C4 Photosynthesis: More than Decarboxylating Enzymes. Frontiers in Plant Science. 7:1525.

Reddy KR, Hodges HF, McKinion JM (1995). Carbon dioxide and temperature effects on pima cotton growth. Agriculture, Ecosystems and Environment. 54:17-29.

Sage RF, Pearcy RW (1987). The Nitrogen Use Efficiency of $C_{3}$ and $C_{4}$ Plants II. Leaf nitrogen effects on the gas exchange characteristics of Chenopodium album $L$. and Amaranthus retroflexus L. Plant Physiology 84: 959-963.

Sayılğan Ç (2016). Küresel Sıcaklık Artıșının Buğdayda Beklenen Etkileri ve Yüksek Sıcaklığa Toleranslılığın Fizyolojik Göstergeleri. YYÜ Tar. Bil. Derg. 26(3): 439447.

Scafaro AP, Haynes PA, Atwell BJ (2010). Physiological and molecular changes in Oryza meridionalis $\mathrm{Ng}$. a heattolerant species of wild rice. J.Exp.Bot. 61: 191-202.

Singh PR, Prasad PVR, Reddy KR (20l3). Impacts of Changing Climate and Climate Variability on Seed Production and Seed Industry. Advances in Agronomy. I 18: 49-84.

Swann ALS, Hoffman FM, Koven CD, Randerson JT (2016). Plant responses to increasing $\mathrm{CO}_{2}$ reduce estimates of climate impacts on drought severity Proc. Natl. Acad. Sci. II3(36): 10019-10024.
Tátrai ZA, Sanoubar R, Pluhár Z, Mancarella S, Orsini F, Gianquinto G (2016). Morphological and Physiological Plant Responses to Drought Stress in Thymus citriodorus. 8 pages. http :// dx.doi.org/I0.II55/2016/4I65750 [Erișim Tarihi: 18.09.2017]

Teng N, Wang J, Chen T, Wu X, Wang Y, Lin J (2006). Elevated $\mathrm{CO}_{2}$ induces physiological, biochemical and structural changes in leaves of Arabidopsis thaliana. New Phytol. 172(1):92-103.

Ton $\mathrm{P}(20 \mathrm{II})$. Cotton and climate change: impacts and options to mitigate and adapt. International Trade Center. Geneva, Switzerland. [Erișim Tarihi: 10.10.2017]

Ulukan H (2010). Global Climate Change, Greenhouse Gases (GHGs) and Cultivated Plants. Ankara University Journal of Environmental Sciences. 2(I): 7I-79.

Vince Ö, Zoltán M (20II). Photosynthetic activity and environmental factors. Plant Physiology, http://www.tankonyvtar.hu/en/tartalom/tamop425/0010 _IA_Book_angol_0I_ novenyelettan /ch03s03.html [Erișim Tarihi: I5.11.2017]

Wang P, Vlad D, Langdale JA (2016). Finding the genes to build C4 rice. Current Opinion in Plant Biology. 31: 4450

Way DA, Katul GG, Manzoni S, Vico G (20|4). Increasing water use efficiency along the $C_{3}$ to $C_{4}$ evolutionary pathway: a stomatal optimization perspective. Journal of Experimental Botany. 65 (13): 3683-3693.

Whiteman PC, Koller D (1967). Interactions of carbon dioxide concentration, light intensity and temperature on plant resistance to water vapour and carbon dioxide diffusion. New Phytol. 66: 463-473.

$\mathrm{Xu} \mathrm{Z}$, Jiang Y, Jia B, Zhou G (2016). Elevated-CO2 Response of Stomata and Its Dependence on Environmental Factors. Frontiers in Plant Sci. Volume 7, Article 657. 
